Check for updates

Department of Primary Care and Public Health, School of Public Health, Imperial College London, London, UK

2 Cambridge University Hospitals NHS Foundation Trust, Cambridge, UK

Correspondence to: $\mathrm{L}$ Shemtob lara.shemtob@nhs.net Cite this as: $B M J 2021 ; 374: n 1975$ http://dx.doi.org/10.1136/bmj.n1975 Published: 11 August 2021

\title{
Vaccinating healthcare workers against covid-19
}

\author{
Compulsion is unnecessary and inappropriate
}

\section{Lara Shemtob, ${ }^{1}$ Mark Ferris, ${ }^{2}$ Kaveh Asanati, ${ }^{1}$ Azeem Majeed ${ }^{1}$}

Parliament's decision to make vaccination against covid-19 a condition of employment for care home workers ${ }^{12}$ has fuelled the debate around compulsory vaccination for healthcare workers, which may follow. ${ }^{3}$ Compulsory vaccination is not a panacea and may harm the safety of patients and healthcare workers, as well as affecting workload and wellbeing. It is a dilemma familiar to occupational health services in many NHS trusts.

Is there a vaccine hesitancy problem in UK healthcare for which mandatory vaccination is an appropriate solution? Data suggesting pockets of poor uptake of covid-19 vaccination among care home staff ${ }^{4}$ led the government to make vaccination compulsory, abandoning a targeted but voluntary approach. The government's Scientific Advisory Group for Emergencies (SAGE) has not published a recommended minimum acceptable level of staff vaccination for healthcare settings, but over $80 \%$ of frontline healthcare workers in NHS trusts have now received two vaccine doses, ${ }^{4}$ reaching over $90 \%$ in some trusts. The level of risk posed by the remaining minority is unlikely to justify policy change at a national level.

Vaccination is already compulsory for staff working in healthcare settings in France and Italy. However, both countries have a history of compulsory vaccinations in response to substantial vaccine hesitancy and outbreaks of vaccine preventable infections such as measles..$^{-7}$ In Italy, legislation introducing compulsory childhood vaccinations was followed by a decrease in the incidence of measles and rubella. ${ }^{8}$ Nevertheless, this policy is under review and may be made more flexible depending on regional vaccine coverage. ${ }^{9}$

\section{Best practice}

Existing guidelines from the Department of Health and Social Care recommend that healthcare workers provide evidence of immunity against measles, mumps, rubella, and varicella zoster virus and comply with vaccination and pre-employment screening for tuberculosis and bloodborne viruses. ${ }^{1011}$ This is not a "no jab, no job" policy: when vaccination is contraindicated or declined, a risk assessment follows to determine whether redeployment is necessary for the safety of patients or co-workers. Unvaccinated people usually continue to work in healthcare, though their practice may be restricted. In the absence of prescriptive guidance from the government, the same process can be followed when covid-19 vaccination is contraindicated or declined.

Redeploying unvaccinated healthcare workers may reduce staffing in some services, but compulsory vaccination can have the same effect. In the recent consultation on mandatory vaccination for care home staff, $61 \%$ of respondents were concerned that the policy would undermine the ability to maintain a safe service. ${ }^{12}$ Possible difficulties include loss of non-compliant staff through redeployment, dismissal, or leaving the sector.

\section{Equality and opportunities}

Some private care homes introduced compulsory covid-19 vaccination for staff in patient facing roles in April 2021. ${ }^{13}$ This predated the parliamentary vote in July, which mandates vaccination of care home workers from October 2021. ${ }^{1}$ No NHS providers have done the same. Although the new policy in care homes should standardise practice across the sector, people declining vaccination now have restricted employment options, which will be further restricted if the policy is extended throughout social care. ${ }^{3}$ In the consultation, $64 \%$ of care home managers said they would dismiss unvaccinated staff compared with $18 \%$ who would redeploy them. ${ }^{12}$ If covid-19 vaccinations become a condition of employment in healthcare, refusing the vaccine could become a career defining decision for clinical staff.

Compulsory vaccination also has implications for employees with protected characteristics under the Equality Act 2010. In the consultation on care homes, an equality impact assessment identified that the policy could disproportionately disadvantage workers from ethnic minority groups, ${ }^{12}$ who are over-represented in the social care workforce and have a lower rate of vaccine uptake than the general population. ${ }^{12}{ }^{14}$ Another risk identified was that compulsion and resultant erosion of trust in government (already low) could further increase vaccine hesitancy among minority groups. These concerns are also relevant to healthcare.

Employee autonomy and support from managers are known to protect against work related stress. Reducing either could damage wellbeing in an already disillusioned workforce. ${ }^{15}{ }^{16}$ Many of the concerns emerging within adult social care are translatable to healthcare, where redundancy and unemployment come with serious and potentially lifelong consequences, including risks to health ${ }^{17}$.

As we understand more about the protection offered by covid-19 vaccination, the arguments for increasing uptake become even more compelling. ${ }^{18}$ Yet vaccination of healthcare workers must be viewed in the context of current best practice in occupational health. The Faculty of Occupational Medicine does not support mandatory covid-19 vaccination as a condition of employment but endorses an "inform and consent” approach. ${ }^{19}$ If vaccination becomes 
mandatory in healthcare settings the occupational fallout could be substantial.

Competing interests: We have read and understood BMJ policy on declaration of interests and have no interests to declare.

Provenance and peer review: Not commissioned; externally peer reviewed.

1 Compulsory vaccinations for care home staff in England backed by MPs. BBC News 2021 Jul 13. https://www.bbc.com/news/uk-57829135

2 Hayes L, Pollock AM. Mandatory covid-19 vaccination for care home workers. BMJ 2021;374:n1684. doi: 10.1136/bmj.n1684 pmid: 34233895

3 NHS England. Covid-19 vaccination Autumn/Winter (Phase 3) planning. 2021. https://www.england.nhs.uk/coronavirus/wp-content/uploads/sites/52/2021/07/C1327-covid-19-vaccination-autumn-winter-phase-3-planning.pdf

4 NHS England. Statistics: covid-19 vaccinations. 5 Aug 2021. https://www.england.nhs.uk/statistics/statistical-work-areas/covid-19-vaccinations/

5 Crollo delle vaccinazioni ai bambini: l'Oms richiama l'Italia. Corriere 2015 Feb 2. https://www.corriere.it/salute/15_febbraio_02/crollo-vaccinazioni-bambini-l-oms-richiama-l-italia09877a56-aaf9-11e4-87bf-b41fb662438c.shtml

6 Italian Ministry of Health. Vaccines law. 2021. https://www.salute.gov.it/portale/vaccinazioni/dettaglioContenutiVaccinazioni.jsp?lingua=italiano\&id=4824\&area=vaccinazioni\&menu=vuoto

7 Government of France. LAW No. 2017-1836 of December 30, 2017 on the financing of social security for 2018. Article 49. 2017. https://www.legifrance.gouv.fr/jorf/id/JORFTEXT000036339090/

8 WHO. WHO vaccine-preventable diseases: monitoring system. 2020 global summary. Italy. https://apps.who.int/immunization_monitoring/globalsummary/countries?countrycriteria\%5Bcountry $\% 5$ D 5 B $\% 5 D=\mid T A$

9 Flexible vaccine obligation plan-Grillo. ANSA2018 Aug 9. https://www.ansa.it/english/news/politics/2018/08/09/flexible-vaccine-obligation-plan-grillo_ebffad1e-32ad-4fcc-acbae2c05173845f.html

10 Department of Health. Health clearance for tuberculosis, hepatitis B, hepatitis C and HIV: New health care workers. 2007. https://assets.publishing.service.gov.uk/government/uploads/system/uploads/attachment_data/file/382152/health_clearance_tuberculosis_hepatitis_hiv.pdf

11 Department of Health, Public Health England. Green book. Immunisation against infectious disease. Chapter 12: Immunisation of healthcare and laboratory staff. https://assets.publishing.service.gov.uk/government/uploads/system/uploads/attachment_data/file/147882/Green-BookChapter-12.pdf

12 Department of Health and Social Care. Consultation outcome. Making vaccination a condition of deployment in older adult care homes. 2021. https://www.gov.uk/government/consultations/making-vaccination-a-condition-of-deployment-in-older-adult-care-homes

13 Peart L. Barchester sets April 23 deadline for staff to take up COVID. Care Home Professional 2021 Feb 24. https://www.carehomeprofessional.com/barchester-sets-april-deadline-for-staffto-take-up-covid-vaccination/

14 MacKenna B, Curtis HJ, Morton CE, etal. Trends, regional variation, and clinical characteristics of COVID-19 vaccine recipients: a retrospective cohort study in 23.4 million patients using OpenSAFELY.medRxiv2021;2021.01.25.21250356. https://doi.org/10.1101/2021.01.25.21250356

15 Health and Safety Executive. What are the management standards? https://www.hse.gov.uk/stress/standards/index.htm

16 Shemtob L, Woolley A.We should protect NHS staff against mental illness just as we protect them against COVID-19.Occup Med 2021;kqab052. doi: 10.1093/occmed/kqab052.

17 Waddell G, Burton AK. Is work good for your health and well-being? An independent review. 2006. https://www.gov.uk/government/publications/is-work-good-for-your-health-and-well-being

18 Milman O, Yelin I, Aharony N, etal. Community-level evidence for SARS-CoV-2 vaccine protection of unvaccinated individuals. Nat Med 2021. doi: 10.1038/s41591-021-01407-5 pmid: 34113015

19 Faculty of Occupational Medicine. COVID-19 guidance on vaccination and testing. Jan 2021. https://www.fom.ac.uk/wp-content/uploads/COVID-19-G

This article is made freely available for use in accordance with BMJ's website terms and conditions for the duration of the covid-19 pandemic or until otherwise determined by BMJ. You may use, download and print the article for any lawful, non-commercial purpose (including text and data mining) provided that all copyright notices and trade marks are retained. 